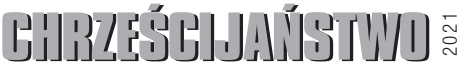

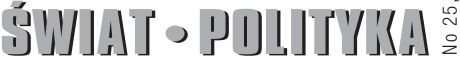 \\ ZESZYTY SPOŁECZNEJ MYŚLI KOŚCIOŁA \\ Peter Schallenberg
}

Theologische Fakultät Paderborn, Germany

ORCID: 0000-0003-2399-1065

\section{The requirement of the state. About the legacy of Ernst-Wolfgang Böckenförde}

\begin{abstract}
Abstrakt: W tekście autor pokazuje, jak prawo naturalne wywodzi się z fundamentalnego nauczania chrześcijańskiego o człowieku i jego relacji z Bogiem. W pierwszym szczegółowym toku myślowym wyjaśnia, przede wszystkim w odniesieniu do myśli Augustyna, że chociaż ludzie mają w sobie również zdolność i tęsknotę za dobrem, to z natury skłaniają się do wybierania nie dobra, ale tego, co jest dla nich przyjemne. Dlatego też z chrześcijańskiego punktu widzenia porządek państwowy jest usprawiedliwiony $\mathrm{z}$ jednej strony po to, aby chronić ludzi przed ich destrukcyjnymi potencjałami, a z drugiej strony wzmacniać wychowanie ku dobru, aby ludzie mogli korzystać $\mathrm{z}$ ich wolności dla dobra, a nie dla tego, co jest dla nich tylko przyjemne. W drugim kroku odnosi to z jednej strony do ustanowienia Unii Europejskiej i związanego z nią kanonu wartości, a z drugiej - w związku z tym do katolickiej nauki społecznej i chrześcijańskiego humanizmu lub personalizmu. Następnie podsumowuje, skupiając się na wielkim niemieckim teoretyku państwa Ernst-Wolfgangu Böckenförde, który pod wpływem katolickiej nauki społecznej i chrześcijańskiego humanizmu sprawił, że rozważania rozwinięte w tekście były owocne dla myślenia o prawie i państwowości we współczesnych demokracjach.
\end{abstract}

Słowa kluczowe: prawo naturalne, humanizm chrześcijański, Augustyn, Unia Europejska, Ernst-Wolfgang Böckenförde, Ritter-School

Abstract: In this text, the author shows how natural law thinking is derived from fundamental Christian teachings about man and his relationship to God. In a first detailed train of thought, he makes it clear, primarily with reference to the thinking of Augustine, that although human beings also have within themselves the ability and longing for the good, they tend by their nature to choose not the good but what is pleasant for them. Therefore, from a Christian point of view, the state order is justified, on the one hand, to protect people from their destructive potentials and, on the other hand, to force education towards the good, so that 
people are enabled to use their freedom for the good and not for what is only pleasant for them. In a second step, he relates this to the founding of the European Union and its associated canon of values on the one hand and, in connection with this, to Catholic social teaching and Christian humanism or personalism on the other. He then concludes by focusing on the great German state theorist Ernst-Wolfgang Böckenförde, who, influenced by Catholic social teaching and Christian humanism, made the considerations developed in the text fruitful for thinking about law and statehood in modern democracies.

Keywords: Natural law, Christian Humanism, Augustine, European Union, Ernst-Wolfgang Böckenförde, Ritter-School

\section{Introduction}

Celebrating in the community of Europe and in an obvious secular context [Wouter 2017: 375-394] the 100th anniversary of the restoration of independence and statehood to the Republic of Poland - "Polonia Restituta" - after more than 120 years of brutal subjugation of the Polish state to the three so-called "Polish divisions", put into place by Russia, Prussia and Austria in 1772, 1793 and 1795, we can reflect on the legacy of Ernst-Wolfgang Böckenförde (1930-2019), the famous catholic philosopher and lawyer, and his important writings concerning constitutional and political theory [2017]. His work is concerned with the link between religion and state, more specifically: the requirement for a good state, or the connection of the image of a person (as a human being) and the image of the state, or the connection of transcendent values and immanent law [Stein 2007].

\section{Image and Education}

In the German language, since the great Dominican preacher Meister Eckhart (1260-1328), influenced by St. Augustine (354-430), Pseudo-Dionysius Areopagita (early 6th century), and St. Thomas Aquinas (1225-1274), "Bildung”, the term used for education and formation, stems from the root word "Bild", which translates as image or archetype. Education, therefore, comprises much more than schooling or upbringing with an envisaged goal in mind. Education and training invariably involve something derived, and secondarily, something we can avail ourselves of. However, in order to be authentic, this derivation and availability must correspond to the unavailable archetype, or the original idea, in short: the first requirement. Such is an ideal that precedes reality. It is an ideal which only after being grasped intellectually enables us to cope with and shape reality and adopt a moral way of living. The idea of good(ness) precedes all forms of insight and action. When and 
insofar as God as Creator is first and foremost identified with being good per es, the biblical transmission of the creation of the world and human beings can be understood in a far more clear-cut and comprehensive manner. This is precisely what is meant by the legendary Garden of Eden in the Old Testament and in the old Israelite tradition: the lost requirement, the lost paradise of ideals, and the Genesis creation narrative describing how humankind was created in the image of God: The core of the first human beings, their primal nature, was intended to be an ideal. Human nature is made good by participating in God's perfect goodness. This is what is meant by the Judeo-Christian terms "creation" and the "creation of the world". It is always oriented towards goodness and God. In other words, good simply means being. Evil is thereby, in the scholastic language of St Thomas Aquinas, privatio boni, "unreal", or the absence of God - which does not detract from the gruesomeness of evil, yet provides consolation by indicating that evil is surmountable [Journet 1962]. According to theological thought since the time of St. Thomas Aquinas and the medieval philosophy and theology after 1250 [Fontana 2018], human beings as individuals can model themselves on the image of God through spiritual activities, or, from the perspective of Greek philosophy, by differentiating between "action" (praxis, agere) and "making" (poiesis, facere). In such terms, making would merely be "indirectly moral in character because it derives value from an object that has been produced. Action, on the other hand, is of moral relevance and is the reason why Aristotle also assumes the existence of a hierarchical order in which praxis is ranked higher than poiesis. The pre-eminence of praxis is made clear in Aristotle's claims that life as whole is a life of praxis since the purpose of life is to live a good life" [Becker 2006: 303]. In this context, the meaning of good is precisely what we in modern times refer to as happiness, or, in other words, living a complete and abundant life together with others. This is the essence of Aristotelian ethics, which was taken up by St. Thomas Aquinas and the modern catholic anthropology and political theology, up to the so called "Ritter-Schule" at the University at Münster (Germany) after the Second World War: everyone aspires to happiness and this needs no justification. It is evident to all that eudaimonia (happy life) is the ultimate goal. However, reaching this goal is dependent on practicing virtues.

\section{Happiness, God, and the evil}

Rejoicing in others as we stand before the happiness of our own life: That is precisely the meaning behind the terms "creation as a gift of God" and "the gift of our own life". Nature and its fortuitousness are interpreted as Creation and divine necessity; this intellectual breakthrough is a highly impressive human 
achievement from a Christian perspective. This ethical surplus crystallizes in the experience of dying and death and here touches upon the reality of faith: "The consequence for how we deal with happiness and the quest for happiness lies in the spiritualization stemming from the Easter dimension of Christian life. Constant transformation springing from hope paves the way forward and creates a biographical axis providing direction and support as we often make risky individual decisions" [Demmer 2008: 11]. Death is the last, inner-worldly insurmountable outer misfortune, or rather, evil, which invariably turns into inner misfortune when it cannot once again be overcome from the outside, thereby transcending the empirical sphere. In Christian theology, overcoming death in this way is called salvation. It represents salvation from the pressures associated with a happiness that is limited in time. This salvation is offered by God in the revelation of human freedom. According to the Gospel of John, God is Spirit. The Gospel of John also refers to the human spirit in its final and no longer unsurpassable potential. At the same time, however, human beings experience themselves as imperfect creatures that, despite their freedom, are already limited with respect to goodness and perfect happiness as a result of their flaws and "original sin". God's creation as the innermost essence of what it means to be human is limited by our innate ability to be led into temptation, toward evil and to sin, which is likewise part of human nature. To sin is to live as though God never existed, to remove all traces of God from our daily life, to doubt the necessity of our own life as given by God and to consider ourselves and others to be nothing more than dispensable particles of dust in the Universe. Therefore, more impetus needs to be given to the essential but broken freedom to achieve good and to fulfill one's purpose. This would serve to counteract such deep-seated mental despair and the growing barrenness of humanity. In other words, people must be incentivized in good conscience to develop and reach out towards goodness. Doing so would ensure such goodness takes a specific shape in their lives and and the resultant gratification would motivate them to live out such goodness every day. However, without weighing up the pros and cons before God, and the will to make sacrifices, such endeavors to achieve goodness will prove unsuccessful. Humankind's inner urge to be good should be encouraged through incentives. Conversely, temptations to do evil should be parried by sanctions. The reason is that human beings lack instinctive and infallible inclinations to achieve goodness and fulfill their true purpose. In fact, human beings have a propensity to behave in a destructive manner toward others and themselves. They chase after what seems to be good but is not. Here we can see that humankind is ensnared in an obsessive quest good in the penultimate, in sin, in evil. According to Christian faith, this is part of 
the human inheritance, even before any personal and individual guilt. Christian faith refers to this as humankind's original sin [Martelet 1986], a deeply rooted lovelessness in all humans, far away from every gnostic and dualistic interpretation [for instance Fromm 1980; Pagels 1991]. Indeed, it is this original sin that thwarts all human striving for good with astounding success. "Impulses are becoming narcissistic and egotistical. Such impulses tend to prevail in a violent manner" [Görres 1991: 18].

\section{Civil law and civil order}

Human beings fulfill themselves within a civilization and the framework of societal and public order. This framework lays the foundation for all ethical tradition which gives grounds for expecting to lead a successful and fulfilled life. In this respect, culture is at the service of human nature's quest for utter perfection, which, in turn lacks in the instincts required to forge a clear path to this end. Every form of higher culture springs from a law of reason, which can be viewed as a critical from of the law of nature: What does every human being, inherently and using their reason, regard as good and perfect? With an eye to ethical standards, this is precisely where the term "human dignity" comes into play. This concept guarantees, in unparalleled clarity, that all individuals are an end in themselves and this applies universally. This is the starting point of a fulfilled existence for every human being. The prime task of ethics, not least social ethics, is thus to determine the interplay between nature and culture and examine the boundary between educating and sanctioning our original nature on a constant basis. Therefore, culture appears to be the necessary ground for a society worthy of humanity. Moreover, culture complements and forms a model for our fractured nature. Human nature still carries a vague memory of the best of this perfect love: the original paradise of a fulfilled life. Yet, such fulfilling happiness cannot be achieved through human nature alone. Fragments of this idea of paradise can be recognized here on Earth, in the human mind and, foremost, in good thoughts. It can only be created in outlines, at least sketchily, through the giving of incentives for action to achieve goodness. According to Immanuael Kant, striving for happiness leads to the Categorical Imperative according to which people have to do what makes them worthy of happiness: living in harmony with themselves as moral beings. Such dignified means of achieving happiness are ingrained in culture. Here, the term that springs to mind is the alienable dignity of human beings as persons, which is to be guaranteed by the state. The state does not originally have its own right, but every person possesses this inalienable basic right. A state (and its monopoly on the legitimate use of force) may only intervene when the 
people's rights are under threat. In the interest of crating a successful image of happiness, promoting human sanctification and perfection must be a matter for both state and society. Both must strive to promote this image. Furthermore, incentives are required for healing and promoting goodness through education and by popularizing guiding principles. Unfortunately, indifference seems to be infiltrating every aspect of our lives. We see this in how the affairs of a state are conducted. It is made evident when a state displays indifference with respect to all values or even goes as far as to absurdly declare itself neutral in this regard. It is manifest when life choices and ways of life are considered equally valid before the law or society. Ultimately, the state, and individuals, will be indifferent. Instead, all that will matter will be the different options belonging to groups of people that differ extremely from one another, or of people who no longer share anything more than the resolute will to survive at all costs. However, qualifying values to such an extent would mark the end of humanity and contradict the notions of human beings as persons [Lewis 1943].

\section{The state and evil}

Let us recall the classic definition of the state given by St. Augustine in his great book "De civitate Dei". There, referring to the Genesis account of the murder of Abel by Cain, St. Augustine underlines the necessity of a so called status iustitiae after the assassination of Abel by Cain, because that episode unleashed complete anarchy. According to this original insight of St. Augustine, a minimal guarantee of a minimal state of minimal justice is the ultimate goal of every state. The purpose and the goal of the state is nothing else than the welfare of its citizen, the human persons, and, for sure, every person, because every human bering, called metaphysically person, is created by God in his image and likeness. As such, every person is gifted with an inalienable dignity and an inherent beauty of the soul, as Plato also affirms in his famous "Myth of Gorgias". In other words: the state has no value without the human person, the bearer of dignity, but the existence of a person is also inconceivable without community and without the state. Without the state, as St Augustine argued, the person is nothing, because the person would be living among an anarchic gang of robbers, as he underlines in the famous forth book of "De civitate Dei": "Remota iustitia quid sunt regna nisi magna latrocinia?" [IV 4]. On account of this unity of reciprocal relationship between the person and the state, the extinction of state and nation is quickly followed by the extinction of the human person. Accordingly, the security of every human being, especially the weak, the unborn and newly born, the handicapped and the dying person, is the sole purpose and "raison d'etre" of a good state, which must be more than a good 
gang of robbers [Mathewes 2010]. These ideas converge obviously in thoughts on personality. Much thinking in the field of personality-psychology is bolstered by the powerful notion of a "human or personal self" which starts as a dim outline and gradually takes shape. The Self is, on closer inspection, considered as a person. As mentioned in Ernst-Wolfgang Böckenförde's famous dictum “The state is living on preconditions which could not be guaranteed by it", state and society are tacitly based on the primary concept of a person who pushes forward towards developing personality and successful self-fulfillment. That promotes an awareness of the absolute singularity and irrevocability of one's own life and of the vocation of every human being to strive towards unmistakable happiness. This is precisely where the notion of the eternal immortality of the human soul takes root, which was formulated paradigmatically by Plato for Western thought and also connected up with the Jewish idea of humankind being irrevocably made in the image of God. The possibility of eternal happiness in God includes the option to turn away from goodness and God for all eternity. In such a case, the true misfortune is no longer one's physical death but rather one's spiritual death, understood as a permanent state of obduracy and the fact of being encapsulated in wrong-doing. Looking back on her reports on the Eichmann trials, Hannah Arendt describes the fatal catastrophe of the normality of wrong-doing and evil: "Evil in the Third Reich had lost the quality by which most people recognize it - the quality of temptation" [Arendt 2006: 150]. Beyond Cain and Abel, as persons of Evil and Good in the Old Testament and therefore inspiring St. Augustine to his differentiation between the state of God (civitas Dei) and the state of the Earth (civitas terrena), a leveling of the difference between good and evil is making ground. For humankind, however, this results in a death more permanent than the physical death itself. Plato, too, found succinct words for such a development: "For death itself no man fears, unless he be an absolute fool or coward; it is doing wrong that a man fears: for to arrive at the world below with the soul laden with many offences is the uttermost of all evils" [Plato 1994: 78]. From that follows the classical principle of a fulfilled existence applicable to all people. This principle is based on the notion "that to do injustice is more to be avoided than to suffer injustice, and that the reality and not the appearance of virtue is to be followed above all things, as well in public as in private life" [ibid.]. The entire human life is one continuous fool's errand consisting of choosing between God and transience, between happiness and satisfaction, between truly self-giving love and illusory, consuming and abusive love [Lewis 2009]. Life choices are enabled firstly by demonstrating a willingness to make sacrifices, which in itself can be deemed a success. This unmistakable calling of all human to educate themselves and make life choices is also the core of all forms of 
solidarity between people within state and a society. Regardless of their achievements and abilities, the notion of humankind as having been created in the image of God thus endowed with dignity is recognized and acknowledged and protected. Christianity sees humankind's endeavors to achieve all-encompassing happiness in the context of suffering and fragmentation, with the talk of original sin recalls. Perfect happiness is not of this world and exists only as an idea, in peoples's mind. Nevertheless, from the perspective of God and in the light of the resurrection of Jesus Christ, every human life however fragmented can therefore in its core and essence be interpreted as happy. This theological idea cannot be annulled by the monstrous malevolence of real people; the state refraining from carrying out the death penalty for instance is a faint echo of it. What needs to be resisted are the insidious attempts to see humankind as nothing more than a consumerist rabbit that responds efficiently to all forms of incentive, or a hard-working ant that can be optimized via technology. This is the temptation to forgo the idea of that every person is worthy of love. Such temptations are countered by the Christian view of humankind and the notion of happiness as salvation from pressures to live a vain life in both time and space.

\section{Europe as a good state}

Against this background, the restoration of Europe in particular as a community of values and virtues is also seen as the creation of a good state. In 1919 Poland was reborn, and in 1957 Europe was reborn, precisely on March 25, 1957 on Capitol Hill in Rome. There six founding states signed a restored Europe into existence. It was hoped that Europe reborn would be the restoration of the old Christian Europe of Emperor Charles LeMagne, who was crowned and anointed on Christmas 800 AD in St. Peter's Basilica in Rome by Pope Leo III, to inaugurate a holy Empire of Christian humanism and of guaranteed dignity of the human person (as an image of God). But this period ended on 6 august 1806 with the abdication of Emperor Francis II in Vienna under napoleonic pressure. The founding fathers of the new and restored Europe are well known: Alcide de Gasperi (1881-1954), born near Trento, then part of Austria, and therefore sensible to the necessity of reconciliation and peace among the different nations. He was educated at the university of Vienna and was cofounder of the famous "Partito Popolare Italiano" after the First World War in Italy; he was a friend of Don Luigi Sturzo, the founder and the first general secretary of this Christian Democratic Party in Italy. Then Robert Schuman (1886-1963), a French Catholic layman, born in Luxembourg, later, after the Second World War, became the Prime Minister of France and was the main author of the famous "Schuman-Plan" for organizing the so called "Montan 
Union", as the precursor of the European Community. Last but not least we have Konrad Adenauer (1876-1967), the first Chancellor of the restored federal republic of Germany after Nazism and the Second World War, also an active catholic and cofounder of the Christian Democratic Union (CDU) after the war. It was not by chance that they were Christian and catholic laymen, and thinking in the famous tradition of a holy empire in the Augustinian tradition of a balance between church and state: the church is essentially the civitas Dei, ruled and sustained by the seven sacraments, as the permanent presence of Christ in the human history, governing the forum internum, the internal market place of every human person with motivation and intention and deliberation about good and evil. The state is the civitas terrena, ruled by law and justice, the forum externum as the external market place of public affairs and public discussions with public arguments, based on the Natural Law, about right and wrong, understandable as the far echo of good and evil, which is seamlessly realized only in the mind of God, in platonic words: in the eternal ideas of God, who overlooks time and eternity. Nor was it by chance that they realized the idea of a European Community on March, 251957 on the Capitol Hill in Rome with a twelve-star flag. These were a triple symbolization of what the European Community project aspired to be: March 25th is the catholic feast day of the Annunciation of Mary's conception and birth of Jesus by the angel Gabriel. In the patristic tradition of the church, Mary's assent to the angel's message and her agreement with God's plan was seen as a sharp contrast to Eve's assent to the serpent's message in the garden of Eden, in Paradise, and her disobedience to God. Thus the feast of the Annunciation also celebrated Mary's "yes" which overturned Eve's "no", thereby inaugurating a new era of restored relationship with God and a renewed and restored humanity. Founding the European Community on the feast of the Annunciation was meant to signal in this community the restoration of God's original idea of a human community in Paradise. The twelve stars of the European Community - when, in fact, there were only six states - refer to the twelve stars in the crown of the "woman clothes with the sun, with the moon under her feet" (Rev 12, 1); and they represent the complete restoration of God's design at the end of time, before the beginning of eternity: the restoration of the twelve Old Testament prophets of Israel in the twelve apostles of the New Testament. Thus, founding the European Community under these symbols meant that the project was also seen as paving the human way in progress toward eternity and God. Capitol Hill symbolized the typology of three hills (or mountains) in old, oriental, and European tradition of human civilization, namely the hill of Golgotha as the hill of God's mercy through the sacrifice of Jesus Christ, the Areopagus as the hill of greek philosophical insight and reflection about natural law and goodness, 
and the Capitol as the hill of Roman Law and the codification of justice against the arbitrariness and against totalitarianism. These three hills were considered as the indispensable and irreplaceable cornerstones, as the requirement for a restored Europe and for the states in this European Community.

\section{The values of Catholic Social Teaching}

After the collapse of communism in Europe in 1989, Poland was restored to its status as a middle European country, and as a country of European greek and Christian tradition and civilization. Against this background of the collapse of communism in Europe, Pope John Paul II wrote his famous Encyclical Letter "Centesimus annus" in 1991, one hundred years after the first papal Encyclical Letter concerning social ethics, "Rerum novarum" of Pope Leo XIII in 1891. In "Centesimus annus" Pope John Paul II wonders whether, in the wake of the collapse of communism, capitalism had now become the only option and, as it were, the sole winner in the battlefield of divergent economic and political ideologies of the late 19th and 20th centuries. He refused to believe in such a vision, especially in a capitalism unqualified by any adjectives. An acceptable form of capitalism for the pontiff would be a "capitalism that is human, integral and person-centred. It would be a capitalism with a human face" [John Paul II 1991: 42], and for that one needs a strong state to steer the market and to guide the economy. It is a social and cognitive capitalism [Rindermann 2019]. Pope Benedict XVI with his Encyclical Letters "Deus caritas est" (2006) and "Caritas in veritate" (2009) and Pope Francis with "Laudato si" (2015) underlines the same perspective and continues the development of a catholic social thought that upholds a real economy at the heart of which finance functions to promote the integral growth and development of the person and a good state. In this sense, the famous "invisible hand" of Adam Smith is not enough [Wight 2015]. One needs the visible hand of the four principles of the catholic social teaching, as four requirements of a good state and a good economy: Personality and Personhood as an expression of every human person's metaphysically added value, understood as a bearer and owner of inalienable dignity; solidarity, not as an vague sense only of compassion, but as a virtue, which encourages one to commit to the wellbeing of another; subsidiarity, according to which "all societies of a superior order must adopt attitudes of help (subsidium) - therefore of support, promotion, development - with respect lower order of societies" [Ponfitical Council Iustitia et Pax 2004: 160]; common good, understood not as a gross national product or gross domestic product, but as the guarantee of personal and associative good, especially in families. The common good of every 
person in a human community is thus the fundamental right to life and to its full realization.

\section{Böckenförde and the legacy of Christian Ethics}

These four basic values as basic requirements of the state are fruits of Christian humanism that inspired Ernst-Wolfgang Böckenförde during his whole life and in all his writings concerning political ethics [Pavelka 2015], especially embossed by his studies in the so called "Collegium philosophicum" at the University of Münster (Germany), founded by Joachim Ritter 1947 and developing the political ideas of Aristotle and Hegel about state and politics in the tradition of a strong and alive natural law. He studied there in this circle together with Hermann Lübbe, Odo Marquard, Robert Spaemann and Ernst Tugendhat [Böckenförde, Ritter 1965]. One basic idea is always underlined: a human being does have priority over the collective and over the state. But the fact, that the person is not self-sufficient in his or her individuality and distinctiveness leads the person to find perfect fulfillment only in a community with other humans, in friendship and love. This is a crucial insight of European Christian humanism and it points to Christ, who, as a person, reveals God as relational love and points the human being to a perfect eternal love as his destiny. Hence, the human is not only an individual person, although gifted by an individual immortal soul [Siedentop 2014], and the human person is bound to requirements as guarantees of life and development, especially the unconditioned right to life. The famous "Böckenförde-Dictum" about the necessity of requirements of the state [Böckenförde 1991: 92-114; Forsthoff 1967: 75-94] underlines this requirement of a secular state: the necessity of a metaphysical natural law as guarantee of the untouchable dignity of every human person and as a nucleus of civil rights [zu Löwenstein 2018]. This is and has to be the heritage of a European Community [Dziedzic 2015: 307-321] and of every type of a state that wishes to be more than, in augustinian words, a civilized gang of robbers. And this is precisely one important legacy of Ernst-Wolfgang Böckenförde [Dreier 2019: 189-214]. 


\section{Bibliography}

Arendt H. (2006), Eichmann in Jerusalem. A Report on the Banality of Evil, New York.

Becker M. (2006), Praxis / Poiesis, in: Wils J-P., Hübenthal C. (ed.), Lexikon der Ethik, Paderborn.

Böckenförde E-W. (1991), Die Entstehung des Staates als Vorgang der Säkularisation, in: Recht, Staat, Freiheit. Studien zur Rechtsphilosophie, Staatstheorie und Verfassungsgeschichte, Frankfurt/Main

Böckenförde E-W. (2017), Constitutional and Political Theory. Selected Writings, Oxford University Press, Oxford.

Böckenförde E-W., Ritter J., Collegium philosophicum, Basel.

Demmer K. (2008), Gott denken - sittlich handeln, Fribourg.

Dreier H. (2019), Staat ohne Gott. Religion in der säkularen Moderne, München.

Dziedzic J. (2015), Die Religiosität und die Bildung von moralischen Haltungen in Europa nach der Wende, in: Van Reeth J. and others (ed.), Secularisation \& Europe.

Fontana S. (2018), La Sapienza dei Medievali. La filosofia cristiana da San Paolo a Guglielmo di Occam, Verona.

Forsthoff E. (1967), Säkularisation und Utopie. Erbracher Studien. Ernst Forsthoff zum 65. Geburtstag, Stuttgart.

Fromm E. (1980), Ihr werdet sein wie Gott. Eine radikale Interpretation des Alten Testaments und seiner Tradition, Hamburg.

Görres A. (1991), Psychologische Bemerkungen über die Erbsünde und ihre Folgen, in: Schönborn C. (ed.), Zur kirchlichen Erbsündenlehre, Freiburg/Br.

John Paul II (1991), Encyclical Centesimus annus, http://www.vatican.va/content/ john-paul-ii/en/encyclicals/documents/hf_jp-ii_enc_01051991_centesimus-annus. html 03.06.2020.

Journet C. (1962), Le Mal. Essai théologique, Bruges.

Lewis C. S. (1943), The Abolition of Man, Oxford University Press, Oxford.

Lewis C. S. (2009), The Great Divorce, London.

Löwenstein zu C. (2018), Christliche werte im Bürgerlichen Recht, Duncker \& Humblot, Berlin.

Martelet G. (1986), La Flaute originelle, la souffrance et la mort, Paris.

Mathewes C. (2010), The Republic of Grace. Augustinian Thoughts for Dark Times, Grand Rapids/Mich. Eerdmans.

Pagels E. (1991), Adam, Eva und die Schlange. Eine Theologie der Sünde, Hamburg.

Pavelka J. (2015), Bürger und Christ. Politische Ethik und christliches Menschenbild bei Ernst-Wolfgang Böckenförde, Academic Press Fribourg, Fribourg.

Plato (1994), Gorgias, Oxford / New York.

Pontifical Council Iustitia et Pax (2004), Compendium of Social Teaching of the Church, http://www.vatican.va/roman_curia/pontifical_councils/justpeace/documents/ rc_pc_justpeace_doc_20060526_compendio-dott-soc_en.html 03.06.2020.

Rindermann H. (2019), Cognitive Capitalism: Human Capital and Well-being of Nations, Cambridge University Press, Cambridge. 
Siedentop L. (2014), Inventing the Individual. The Origins of Western Liberalism, Harvard University Press, Harvard.

Stein T. (2007), Himmlische Quellen und irdisches Recht. Religiöse Voraussetzungen des freiheitlichen Verfassungsstaates, Campus Verlag Frankfurt/Main.

Wight J. B. (2015), Ethics in Economics. An Introduction to Moral Frameworks, Stanford University Press, Stanford.

Wouters J. (2017), The Place of Religion and Churches in the European Union, in: Van Reeth J., Pottier B., Slawinski H., De Rycke F. (ed.), Secularisation \& Europe, 's-Hertogenbosch, Kraków. 